\title{
Review
}

Intervirology

Intervirology 2013;56:67-83

Received: June 21, 2011

DOI: $\underline{10.1159 / 000342301}$

Accepted after revision: July 28,2012

Published online: January 22, 2013

\section{Epidemiology of Mammalian Hepatitis E Virus Infection}

\author{
Mamadou Kaba a, b Valérie Moal ${ }^{c}$ René Gérolami ${ }^{d}$ Philippe Colson $^{a}$ b \\ ${ }^{a}$ Aix-Marseille Université, URMITE UM63 CNRS 7278 IRD 198 INSERM U1095, IHU Méditerranée Infection, Facultés de \\ Médecine et de Pharmacie, ${ }^{\text {b}}$ Pôle des Maladies Infectieuses et Tropicales Clinique et Biologique, Fédération de \\ Bactériologie-Hygiène-Virologie, Assistance Publique des Hôpitaux de Marseille, Centre Hospitalo-Universitaire \\ Timone, ' Centre de Néphrologie et Transplantation Rénale, Centre Hospitalo-Universitaire Conception, Assistance \\ Publique des Hôpitaux de Marseille, Aix-Marseille Université, and d'Service d'Hépato-Gastro-Entérologie, Centre \\ Hospitalo-Universitaire Conception, Assistance Publique des Hôpitaux de Marseille, Marseille, France
}

\section{Key Words}

Hepatitis Evirus • Epidemiology · Autochthonous hepatitis E • Zoonosis - Zoonotic transmission - Foodborne transmission • Pig $\cdot$ Prevention $\cdot$ Vaccine

\begin{abstract}
Mammalian hepatitis E virus (HEV), the etiological agent of hepatitis $E$ in humans, is a recently discovered infectious agent. It was identified for the first time in 1983 using electron microscopy on a faecal specimen of a person infected with non-A, non-B enterically-transmitted hepatitis. Based on retrospective and prospective studies, HEV was long described as one of the leading causes of acute viral hepatitis in tropical and subtropical countries, whereas in developed countries hepatitis E was considered an imported disease from HEV hyperendemic countries. Data from studies conducted during the past decade have greatly shifted our knowledge on the epidemiology and clinical spectrum of HEV. Recently, it has been shown that contrary to previous beliefs, hepatitis $E$ is also an endemic disease in several developed countries, particularly in Japan and in Europe, as evidenced by reports of high anti-HEV immunoglobulin G prevalence in healthy individuals and an increasing number of non-travel-related acute hepatitis E cases. Moreover, a porcine reservoir and growing evidence of zoonotic trans-
\end{abstract}

mission have been reported in these countries. This review summarizes the current knowledge on the epidemiology and prevention of transmission of mammalian HEV.

Copyright $\odot 2013$ S. Karger AG, Basel

\section{Introduction}

Mammalian hepatitis E virus (HEV), the etiological agent of hepatitis $\mathrm{E}$ in humans (previously known as nonA, non-B enterically-transmitted hepatitis virus), is a disease of worldwide distribution [1], usually transmitted by the oral-faecal route via contaminated water [2-6]. The first indication of the circulation of an enterically-transmitted non-A, non-B hepatitis virus came from two independent studies conducted in India in the 1980s [7, 8]. In these studies, retrospective analyses of serum samples collected during epidemics of jaundice that occurred from December 1955 through January 1956 in New Delhi [8], and November 1978 through January 1979 in Kashmir [7], indicated the existence of a new enterically-transmitted hepatitis agent circulating in India. The viral hepatitis agents $\mathrm{A}$, and/or $\mathrm{B}$, were excluded, and anti-HEV antibodies were detected using serological assays $[9,10]$.

HEV was visualized for the first time in 1983 by Balayan et al. [11] using electron microscopy on faeces of a vol-

\section{KARGER}

Fax +41613061234

E-Mail karger@karger.ch

www.karger.com
(C) 2013 S. Karger AG, Basel

$0300-5526 / 13 / 0562-0067 \$ 38.00 / 0$

Accessible online at:

www.karger.com/int
Philippe Colson, Pôle des Maladies Infectieuses et Tropicales Clinique et Biologique

Fédération de Bactériologie-Hygiène-Virologie, IHU Méditerranée Infection

Centre Hospitalo-Universitaire Timone, 264 rue Saint-Pierre

FR-13385 Marseille Cedex 05 (France)

E-Mail philippe.colson@univmed.fr 
Fig. 1. Number per year of publications and nucleotide HEV sequences found in the NCBI PubMed database and GenBank nucleotide sequence database, respectively, using the keywords 'hepatitis E virus' and 'hepatitis E'.

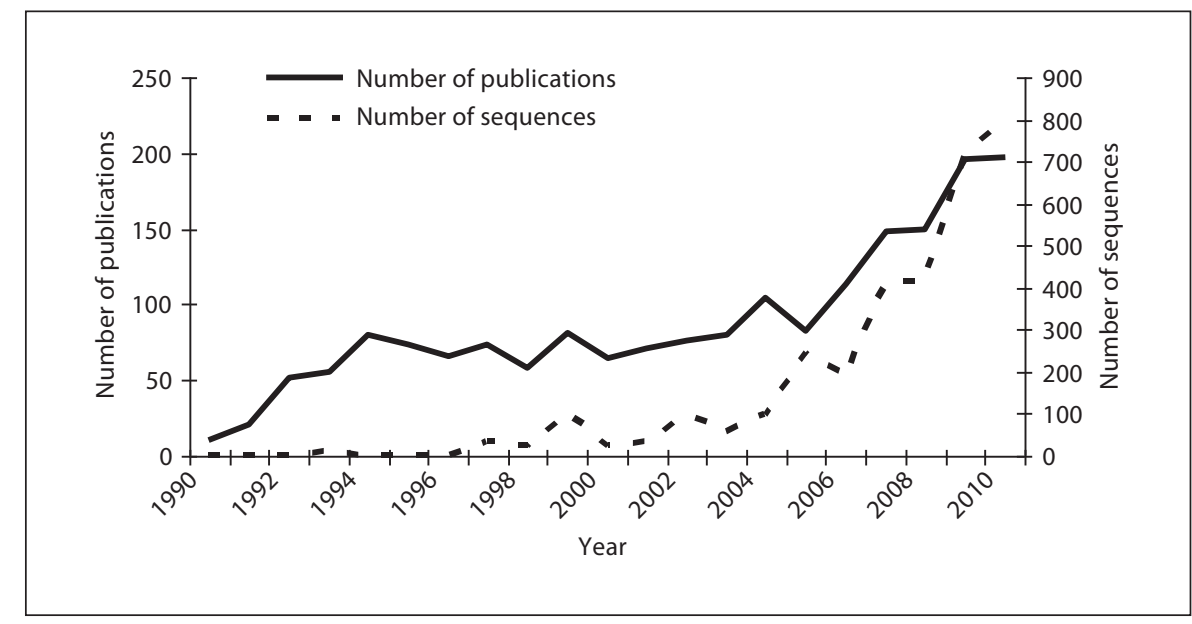

unteer (Balayan himself) who ingested extracts of purified pooled faeces collected from patients suspected of non-A, non-B enterically-transmitted hepatitis contracted during a 1981 hepatitis epidemic in a Soviet military camp in Afghanistan. Its genetic organisation was only characterized 7 years later, in 1990 by Reyes et al. [12] through the cloning and sequencing of an isolate of HEV from Burma.

Based on retrospective and prospective studies, HEV was long described as one of the leading causes of acute viral hepatitis in tropical and subtropical countries, whereas in developed countries hepatitis E was considered as an imported disease from developing countries [13]. Data from studies conducted during the past decade have greatly shifted our knowledge on the epidemiology and clinical spectrum of HEV [14-23]. Recently, it has been shown that contrary to previous beliefs, hepatitis $\mathrm{E}$ is also an endemic disease in several developed countries $[14,18-$ 23], especially in Japan and parts of Europe. This new face of hepatitis $\mathrm{E}$ has been indicated by reports of high antiHEV immunoglobulin (Ig) G prevalence in healthy individuals and an increasing number of acute hepatitis $\mathrm{E}$ in patients with non- $A$, non-B, non- $C$ hepatitis who did not visit HEV-hyperendemic countries during a period compatible with the incubation of the disease ( 40 days on average), or have contact with travellers from these geographical areas [14, 15, 18-23]. Moreover, a porcine reservoir and growing evidence of zoonotic transmission have been reported in developed countries [14, 15, 24-29]. Furthermore, possible progression towards chronic hepatitis $\mathrm{E}$ and hepatitis E-associated cirrhosis were observed in severely immunocompromised patients [16, 17, 30-34]. These findings led to a resurgence of the interest in research on HEV, as indicated by nearly a doubling of the number of papers published annually in peer-reviewed journals referenced in the NCBI PubMed database over the last 5 years (fig. 1). Concurrently, the number of HEV RNA sequences available in the NCBI GenBank database showed a similar trend (fig. 1). This review summarizes the current knowledge on the epidemiology and prevention of transmission of mammalian HEV.

\section{Taxonomy, Basic Virology and Genome Organisation}

Until 2005, the taxonomy of HEV remained unresolved [35]. At first, HEV was tentatively classified into the Caliciviridae family based on its morphological similarities and physicochemical properties [36]. However, because the genomic organisation of HEV is significantly different from caliciviruses and any other viruses, HEV has been reclassified in a new family, the Hepeviridae family, genus hepevirus [35, 37].

HEV is a small non-enveloped icosahedral in shape virus; its diameter is approximately $27-34 \mathrm{~nm}[11,35,36]$. The HEV genome is a single-stranded, linear, positivesense RNA of approximately 7.5 kilobases $(\mathrm{kb})$ in length $[12,35,38]$. This genome (fig. 2 ) is capped at the $5^{\prime}$-end, polyadenylated at the $3^{\prime}$-end, and contains a short $5^{\prime}$ untranslated region of 27 nucleotides, three discontinuous partially overlapping open reading frames (ORF) and a short $3^{\prime}$ untranslated region of 65 nucleotides [35, 38, 39]. ORF1, which extends about $5 \mathrm{~kb}$ from the $5^{\prime}$-end of the HEV genome and constitutes the most variable region of the genome, codes for a non-structural polyprotein (including methyltransferase, papain-like cysteine protease, 
Fig. 2. Schematic of the genome of HEV. Nucleotide positions correspond to the HEV strain described by Tam et al. [38]. Met $=$ Methyltransferase; $\mathrm{Y}=$ domain $\mathrm{Y}$; $\mathrm{PCP}=$ papain-like cysteine protease; $\mathrm{Pr}=$ proline; $\mathrm{X}=$ domain $\mathrm{X} ; \mathrm{H}=\mathrm{RNA}$ helicase; RdRp = RNA-dependent RNA polymerase; $\boldsymbol{\Lambda}$ = glycosylation site.

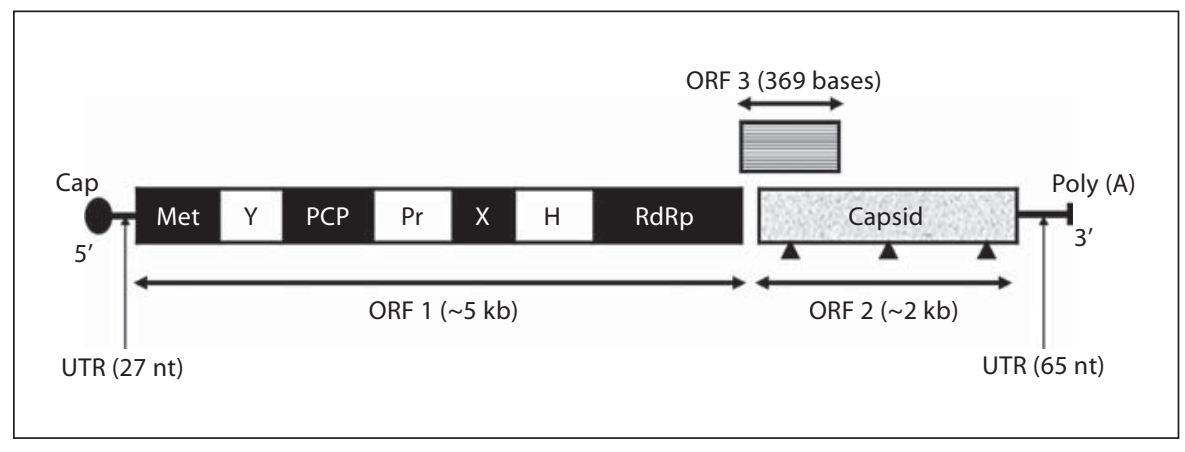

RNA helicase and RNA-dependent RNA polymerase) involved in viral genome replication [37-39]. ORF2, located at the $3^{\prime}$-end of the HEV genome, is about $2 \mathrm{~kb}$ in length and codes for the viral capsid protein and is involved in most capsid-related functions, such as virion assembly, interaction with host cells and immunogenicity $[38,39]$. In addition, ORF2 contains a typical signal peptide sequence and three potential glycosylation sites [39]. Mutations in these glycosylation sites have been shown to prevent the formation of infectious particles from transfected replicons [39]. The third and the smallest ORF of the HEV genome (ORF3, of approximately 369 bases in size) overlaps the first ORF by one nucleotide at the 5 '-end and shares most of the remaining sequence ( $328 \mathrm{bp}$ ) with the ORF2 [38, 39]. ORF3 codes for an immunogenic phosphoprotein with several functions, such as virion morphogenesis and release [39].

\section{Epidemiology}

\section{HEV Genotypes and Their Geographic Distribution}

All HEV strains belong to a single serotype [40], but based on genetic diversity of HEV sequences, four phylogenetically distinct HEV genotypes (1-4) [35] and 24 subtypes [41] have been defined. However, due to the recent identification in various animal species (wild Norway rats, Rex rabbits, wild boars and bats) of HEV strains genetically distinct to the four recognized HEV genotypes, the genotypic classification of HEV might evolve [42]. For example, the HEV recovered recently from rats and bats in studies conducted in Germany appear to belong to two new mammalian HEV genotypes based on phylogenetic analysis [42].

The geographical distribution of HEV genotypes is complex and changing (table 1). Genotypes 1 and 2 only infect humans and are responsible for both epidemic and sporadic hepatitis E cases occurring in tropical and subtropical countries [1, 4-6, 41, 43-47]. Genotypes 3 and 4 have been shown to infect not only humans, but also domestic animals throughout the world, especially pigs and wild boars $[1,14,15,18,19,23,25-28,48,49]$. Genotypes 3 or 4 are responsible for autochthonous (i.e. locally-acquired) sporadic hepatitis E cases in America, Europe, Oceania and Asia $[1,14,15,18,19,21-23,50]$. HEV genotype 4, which is indigenous to Asia, was recently described in swine in Belgium [51] and in travel-unrelated hepatitis E cases in Germany and France [23, 49].

\section{Evolutionary Relationship among HEV}

The discovery in a pig in 1997 of genotype $3 \mathrm{HEV}$ with close relationship to strains recovered in humans [52] raised questions regarding the origin and evolution of HEV. HEV is currently the sole member of the Hepeviridae family [35]. Twenty years ago, in 1992, based on the analysis of the polymerase and helicase sequences of positive-strand RNA viruses, Koonin et al. [37] grouped HEV with rubella virus and beet necrotic yellow vein virus (a plant virus). Recently, Purdy and Khudyakov [53] performed a Bayesian analysis on curated sets of 43 ORF1 sequences, 48 ORF2 sequences and 54 ORF3 sequences with known dates of collection [53]. They tentatively estimated that the most recent common ancestor for modern HEV genotypes 1-4 existed between 536 and 1,344 years ago [53]. They described that HEV ancestors may have evolved into anthropotropic and enzootic viruses, which gave rise to genotypes 1 and 2, and genotypes 3 and 4, respectively [53]. Moreover, Purdy and Khudyakov [53] estimated the time of divergence from the ancestor of avian or rat and genotype 1-4 HEV sequences at about $1.4 \cdot 10^{6}$ and $7.4 \cdot 10^{4}$ years ago, respectively. In addition, 
Table 1. Geographical distribution of HEV infections according to the genotypes

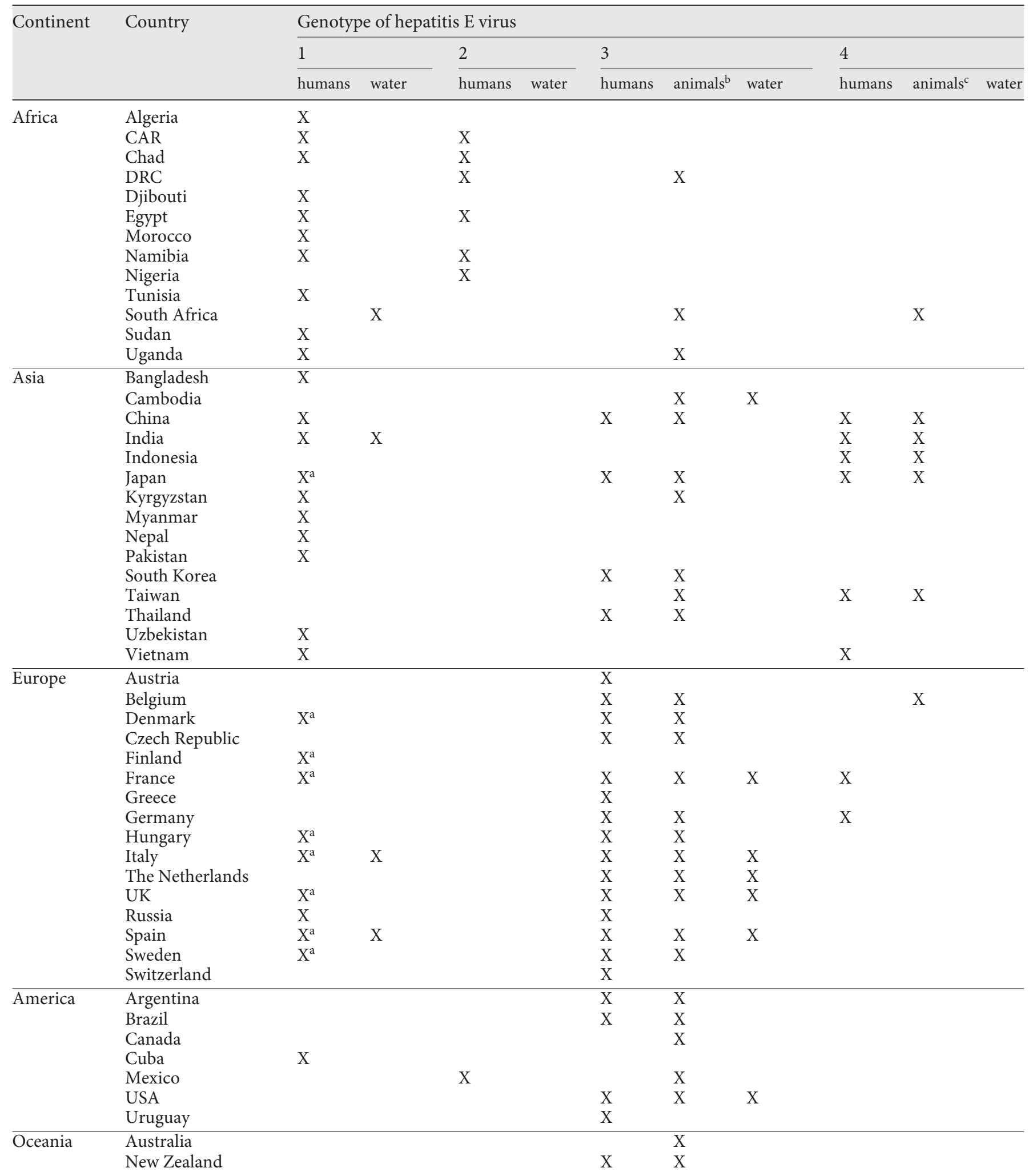

CAR $=$ Central African Republic; DRC $=$ Democratic Republic of the Congo.

a Probable cases imported from an endemic area for genotype $1 \mathrm{HEV}$. ${ }^{\mathrm{b}}$ At least one positive sample from domestic pigs, wild boars, deer, mongoose or any combination. ${ }^{c}$ At least one positive sample from domestic pigs, wild boars or any combination. 
they explained that HEV genotypes 3 and 4 may have expanded starting around the end of the 19th century until World War II, and that genotype 3 experienced an additional increase in population size until approximately 1960. Both genotypes 3 and 4 may have undergone a rapid decline in population size to pre-expansion levels since approximately the year 1990 [53]. Regarding genotype 1, its expansion was dated approximately $30-35$ years ago [53]. Overall, results of this study suggested that the HEV ancestors may have adapted in a stepwise manner to various successive animal hosts, which led to human hosts. Besides, Xia et al. [54] analysed 80 full-length HEV genomes using Bayesian analysis and reported that genotypes 3 and 4 strains recovered from swine were paraphyletic with regard to strains recovered from humans, which appeared phylogenetically nested among pig strains. Recombination events in HEV have been reported [55]. The recombination events could be a consequence of co-infection or superinfection of the host. The dual infection of a single host by HEV of two different genotypes and two different subtypes has been documented in humans [56]. The possibility of superinfection with HEV has recently been documented in pigs in Spain by de Deus et al. [57], showing that the same pig can be infected by at least two different strains of HEV during its productive life. The nucleotide similarity between the two HEV sequences obtained from the same pig at 1 and 15 weeks of age was $84 \%$ [57]. Moreover, HEV quasi-species have been described [58]. Intrapatient HEV sequence diversity of the Tanefdour (Algeria) hepatitis E epidemic (between 1986 and 1987) ranged between 0.11 and 3.4\% [58].

\section{Routes and Sources of HEV Transmission}

The route of HEV transmission during outbreaks is well established, and was usually associated with the consumption of faecally contaminated drinking water [2-6, $9,10,43,59]$. In contrast, it is poorly documented for sporadic hepatitis $E$ cases reported in both developing and developed countries $[14,21,44,60]$. To date, four major documented routes of HEV transmission have been reported: waterborne transmission [2-8, 61]; foodborne transmission [29, 48]; bloodborne transmission [62, 63], and vertical transmission [64-66]. Person-to-person HEV transmission is rarely reported and is considered as an uncommon event, both in the context of outbreaks and sporadic infections $[67,68]$. HEV nosocomial transmission [69] and accidental transmission in the laboratory [70] were also reported. Finally, a case of HEV infec- tion transmitted via an infected graft after orthotopic liver transplantation has been recently reported in Germany [71]. The infectious titer for HEV is not known precisely but could be estimated through several experimental studies, and may be approximately $10^{4}-10^{7}$ genome equivalents per millilitre $[1,72]$.

\section{Waterborne Transmission}

In developing countries of Asia, Africa and Latin America, the faecal-oral route through drinking contaminated water is the principal route of HEV transmission, and is responsible for the majority of hepatitis $\mathrm{E}$ outbreaks occurring in these areas [2-8, 59, 61, 73-75]. These outbreaks usually occur during the rainy season, floods or the monsoon, conditions facilitating contamination of pipes, groundwater and sources of drinking water by human excreta $[6-8,59]$. The common characteristic for the majority of the hepatitis E outbreaks is drinking unchlorinated water containing an elevated rate of coliform organisms $[74,75]$. Nevertheless, drinking chlorinated water does not exclude the occurrence of hepatitis E outbreaks, as shown in a refugee camp in Darfour, Sudan [61]. Therefore, further studies are needed to evaluate the concentration of chlorine required to inactivate HEV in drinking water, but also to identify other appropriate environmental measures enabling the reduction of the risk of HEV transmission by the faecal-oral route. Case-control studies have shown that consumption of boiled water significantly reduced the risk of epidemic HEV infection $[6,59]$. Strong arguments supporting the faecal-oral transmission of HEV during hepatitis E outbreaks came from recent studies conducted in India and Uganda [3, 4, 73]. Environmental investigations showed the presence of HEV RNA (of genotype 1) in river water samples collected during hepatitis E outbreaks in India [3,73], and the presence of HEV RNA in common hand washing water collected during the Kitgum District (Uganda) hepatitis E outbreak [4]. Interestingly, in the Alandi (India) hepatitis E outbreak, partial HEV sequences from patients infected with HEV and water samples were identical [3]. Besides, HEV of genotype 1 has been detected in drinking water treatment plants in Egypt and India, and sewage in India [73, 76]. In addition, a 12 -fold (range, 2-78) higher risk of anti-HEV seropositivity was found in Turkish agricultural workers (35\%) who used untreated waste water for irrigation compared to a control group (4\%) [77]. Of note, HEV of genotype 3 has been recently detected in river water in Cambodia [78]. This report suggests that waterborne hepatitis $\mathrm{E}$ of genotype 3 might occur in developing countries. 


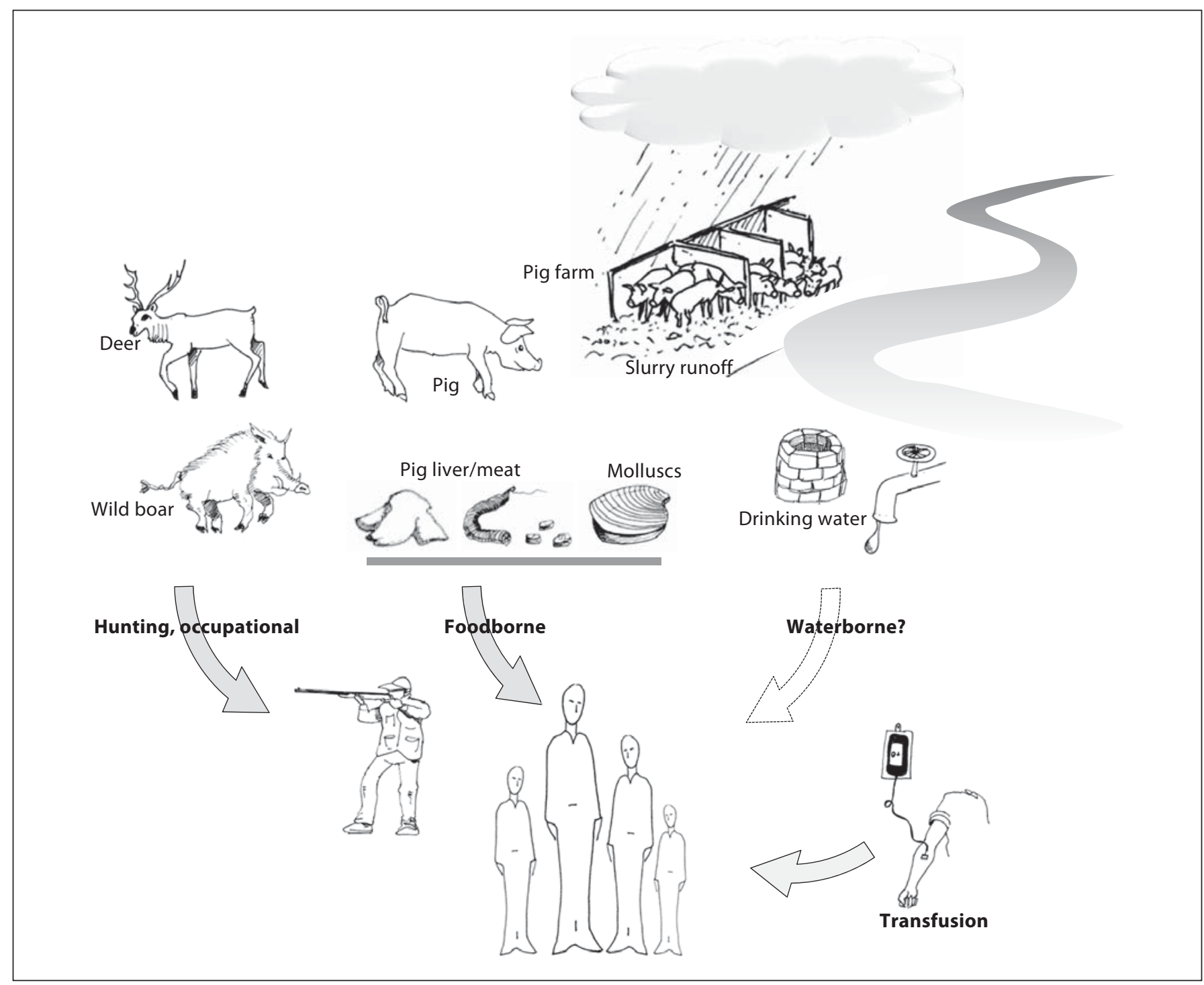

Fig. 3. Schematic drawing of documented and possible sources and routes for autochthonous HEV transmission to humans in developed countries.

In developed countries, evidence of HEV transmission through the faecal-oral route has not been reported until now, although infectious HEV of genotype 3 has been isolated from sewage or a drinking water treatment plant $[60,79,80]$. However, this mode of contamination cannot be excluded, and could be related to drinking water contaminated by HEV or consumption of food items receiving sewage sludge, such as shellfish (fig. 3). In South Korea, an oyster HEV strain of genotype 3 phylogenetically close to HEV recovered from a South Korean pig has been reported [81]. In Canada, HEV RNA has been detected on irrigated, field-grown strawberries [82]. In addition, drinking water from non-public supplies was identified as a risk factor for acquiring hepatitis E in Spain [83] and France [20]. Therefore, as in developing countries, the environment should be considered as a potential source of HEV transmission in developed countries. This hypothesis is supported by the finding of Borgen et al. [60] in the Netherlands, who showed a $100 \%$ identity between HEV RNA detected in a patient infected with HEV and that of a surface water sample taken in the close surroundings of the patient. In another study conducted in the Netherlands, HEV RNA was detected in $17 \%(2 / 12)$ of surface water samples collected from the Meuse River, and 
showed high nucleotide similarity with HEV recovered from humans in the same geographical area [79]. Finally, a hepatitis E case acquired following intense exposure to waste-water sludge has been reported in France [84]. Of note, HEV RNA of genotype 1 has been detected in urban sewage and biosolids (treated sludge) in Spain [80]. This finding was unexpected, and therefore suggests that contracting of non-travel-related hepatitis $\mathrm{E}$ of genotype 1 cannot be excluded in developed countries.

\section{Zoonotic Transmission}

Under non-experimental conditions, the hypothesis of zoonotic transmission of HEV was suggested for the first time in 1997 by Meng et al. [52]. They described a genotype $3 \mathrm{HEV}$ strain from a pig in the USA, which showed high nucleotide and amino acid similarity with human HEV sequences [52]. The zoonotic transmission of HEV was confirmed by the experimental demonstration of cross-species transmission of human HEV to pigs and of pig HEV to non-human primates [72], but also by several studies that showed a strong phylogenetic link between HEV RNA recovered from humans and other mammals (especially pigs, wild boars and deer), including meat and derived products (fig. 3) $[15,24,25$, 27, 29, 48]. Furthermore, HEV has been detected in pig livers or pigliver sausages purchased in supermarkets $[15,24,85]$, and the infectivity of some of them was proven $[85,86]$.

\section{Foodborne Zoonotic Transmission}

The strongest evidence of zoonotic transmission of HEV has come from studies conducted in Japan, and was associated with eating not thoroughly cooked deer or wild boar meat $[29,48]$. HEV sequences recovered from leftover frozen meats and from patients infected with HEV were identical [29, 48]. Further evidence supporting the zoonotic transmission of HEV is through the consumption of contaminated raw or undercooked food products from pigs purchased in supermarkets or from wild boars, although the leftover meats were not available for HEV testing $[15,23,24,60,87]$. HEV sequences recovered from suspected commercial pig livers or pig liver sausages were closely related, or identical in some cases, with those recovered from patients infected with HEV [15, 24, 62]. For example, in Marseille (France), HEV RNA sequences recovered from hepatitis E patients who ate uncooked pig liver sausage were closely related to those recovered from figatelli, with nucleotide identity $>99 \%$ [24]. In addition, based on case-control studies conducted in France and Germany, consumption of uncooked pig liver sausage, game meats or offal was identified as a risk factor for HEV infection $[23,24,88]$. Another argument in favour of zoonotic foodborne transmission of HEV is the finding in Indonesia of significantly higher HEV seroprevalence in Hindu people, who eat pig meat, than in Moslem people, who do not eat pig meat [89]. In addition, in a study conducted in Japan by Toyoda et al. [90], anti-HEV antibodies detection was significantly different between hunters who reported the consumption of undercooked or raw boar meat and those who did not $(\mathrm{p}=0.002)$. Thus, the prevention of foodborne zoonotic transmission of HEV could consist of avoiding consumption of undercooked meats and other derived products from animals identified as potential reservoirs of HEV. Of note, it has been shown that $\mathrm{HEV}$ in contaminated pig livers can be inactivated if cooked at an internal temperature of $71^{\circ}$ for $5-20 \mathrm{~min}$, boiled in water for $5 \mathrm{~min}$, or fried at $191^{\circ}$ for $5 \mathrm{~min}$; in contrast, incubation at $56^{\circ}$ for $1 \mathrm{~h}$ can be insufficient for viral inactivation [86].

\section{Non-Foodborne Zoonotic Transmission}

Direct contact with animals, such as pigs, wild boars, deer and cats, working in a pig slaughterhouse or being exposed to pig blood during surgical training have been identified as potential risks for zoonotic transmission of HEV (fig. 3) [14, 15, 90-92]. A high prevalence of anti$\mathrm{HEV}$ antibodies has been found in veterinarians and staff of pig farms as opposed to the general population $[14,15]$. In studies conducted in France and Japan, hunting has been found to be associated with the higher prevalence of anti-HEV antibodies in blood donors [90, 92]. For instance, in the Japanese study, anti-HEV seroprevalence was significantly higher in wild boar hunters than in the control group ( $p<0.0001$ ) [90]. Finally, contact with horses and pets have been associated with a higher prevalence of anti-HEV antibodies in multivariate analysis $[93,94]$. Besides, due to the fact that pigs raise major interest in xenotransplantation [95] and are concurrently considered as a potential reservoir of HEV, the xenografts of tissue, organs and cells of pigs have been considered as a possible source of HEV transmission in transplant patients, but no evidence of such transmission has been published so far.

\section{Non-Zoonotic Foodborne Transmission}

Foodborne transmission of HEV linked to shellfish consumption has been suspected in Italy, the UK and France $[14,20,96]$. In a study conducted in the UK by Said et al. [96], consumption of shellfish was identified as the only risk factor during a hepatitis E outbreak in patients 
returning from a cruise around the world in March 2008. Epidemiological investigation of this outbreak showed that of 789 individuals who provided blood samples, 195 (25\%) were seropositive, 33 (4\%) had IgM anti-HEV antibodies and $162(21 \%)$ had anti-HEV IgG antibodies. The sequencing of HEV RNA from 3 case patients showed that they belonged to genotype 3 and were genetically close to the genotype $3 \mathrm{HEV}$ circulating in Europe [96]. Additionally, evidence that shellfish can be a source of HEV transmission to humans was provided by the detection of HEV RNA of genotype 3 in bivalve molluscs in Japan [97] and in oysters in South Korea [81].

\section{Parenteral Transmission}

Direct and indirect arguments in favour of transmission of HEV through blood transfusions in humans have been reported [62, 63, 98-100]. Direct evidence was reported in France, Japan and the UK $[62,63]$; HEV sequences from the donor and recipient were identical [62, 63]. Indirect evidence of $\mathrm{HEV}$ transmission through blood transfusion is the finding of individuals who have seroconverted to anti-HEV antibodies (IgG or IgM) after a blood transfusion [98], the high prevalence of anti-HEV IgG antibodies in blood donors in several other studies $[92,100,101]$ and statistically significantly higher prevalence of anti-HEV IgG antibodies among multitransfused patients compared to control groups [102]. Transmission of hepatitis E virus through blood transfusion may be favoured by the existence of a phase of viraemia of at least 2 weeks during the pre-icteric phase of infection [103-105] and the existence of symptom-free HEV infections [103-106]. Of note, in most countries, including developed countries, ALT level is not tested in blood donors. The interest of ALT testing in blood donors was demonstrated in several studies conducted in Japan [99], and one study in Germany [104], showing that on-going (defined by the HEV RNA detection) and/or recent HEV infection (defined by anti-HEV IgM detection) can be detected in blood donors with elevated ALT level [99]. In China, Guo et al. [106] found HEV RNA in $0.07 \%(30 / 44,816)$ of eligible blood donors. Also, it has been found that HEV viraemia in blood donors can exceed $7 \log _{10}$ HEV RNA copies/ml [99]. Recently, Baylis et al. [107] screened 95,835 Swedish, 18,100 German and 51,075 American plasma donations for the presence of HEV RNA in plasma minipools of up to 96 donations. They found that 12 (representing 1:7,986 donations), 4 (representing 1:4,525 donations) and 0 donations for Swedish, German and American donors, respectively, were HEV RNA positive. Molecular characterization of 12 out of the 16 HEV RNA- positive samples indicated that all cases belonged to HEV of genotype 3. Viral loads varied between 3.2 and $5.7 \log _{10}$ $\mathrm{IU} / \mathrm{ml}$. Noteworthy, using the solid-phase enzyme-linked immunosorbent assays from the Wantai Pharmaceutical Company (Beijing, China), one viraemic sample was antiHEV IgM-positive and another was anti-HEV IgG-positive [107]. In another work, of 75 plasma fractionation pools analysed for the presence of HEV RNA, 8 were positive including 3/34 from Europe, 1/4 from North America, 0/11 from the Middle East and 4/23 from Southeast Asia [108]. Genotype 3 viruses were found in European and North American pools and genotype 4 viruses were identified in Asian pools. None of the positive pools exceeded a load of 1,000 copies/ml. Only Asian pools were found to have detectable anti-HEV IgG antibodies [108]. In England, Ijaz et al. [109] detected HEV RNA in 6/880 $(0.7 \%)$ plasma mini-pools collected in 2007 and made up from 48 individual blood donors $(42,000$ individual donors). In HEV RNA-positive pools, HEV load was low $(<2,000 \mathrm{GEq} / \mathrm{ml})$. Anti-HEV IgG and IgM antibodies were detected in 6 and 1 cases, respectively. These previous results raise concern on the consequences of $\mathrm{HEV}$ contamination of blood and plasma. It is noteworthy that in the UK, about $75 \%$ of blood or blood components are administered to immunocompromised patients, who are at risk of chronic HEV infection [109].

Apart from transfusion of blood or derived products, a nosocomial hepatitis E outbreak with an overall ward attack rate of $15.9 \%$ (18 out of 113 patients) was reported in a neurosurgery ward in Karachi, Pakistan; inappropriate practice of shared intravenous administration was identified as the risk factor [69]. Furthermore, the possibility of parenteral transmission of HEV in groups at risk, such as haemodialysis patients, haemophilia patients and intravenous drug users, has been suggested, although conflicting data exist [110-112].

\section{Vertical Transmission}

The transmission of HEV from mother to child has been reported in India and in the United Arab Emirates based on serological and/or virological evidence [64-66]. The transmission rate ranged from 33 to $100 \%$ [64-66], and the neonatal mortality can reach up to $40 \%[64,65]$. On the experimental level, vertical transmission of HEV infection was not reproduced in Rhesus monkeys and in gilts [113]. Besides, although anti-HEV IgG antibodies and HEV RNA have been detected in the colostrum of HEV-infected mothers, breastfeeding was not associated with HEV transmission to infants [114]. 


\section{Burden of HEV Infection}

\section{HEV Infection in Humans}

It is difficult to estimate the burden of HEV infection in a population due to the significant variability in sensitivity and specificity between the assays used for the diagnosis of HEV infection [101, 108, 115, 116]. Another difficulty is that there is limited access to HEV diagnosis assays in several countries worldwide, and misdiagnosis of some symptomatic hepatitis E cases is a possibility, as shown in recent studies [115, 116]. Moreover, the duration of persistence of antibodies against $\mathrm{HEV}$ is poorly understood [34, 117-120]. Similarly, data concerning the seasonality of sporadic hepatitis E cases occurring throughout the year in both developed and developing countries are scarce $[21,22,121,122]$. A seasonal variation in the occurrence of hepatitis E cases has been observed in studies conducted in the UK [22], Japan [121] and China [122]. In contrast, no seasonal variation was observed in the occurrence of hepatitis E cases diagnosed between 2003 and 2007 in the Midi-Pyrénées region of France [21]. In Southwest England, from 1999 through 2006, the peak of hepatitis $E$ cases was recorded in spring and summer [22]. In Japan, at Tohoku University Hospital in Sendai (between January 1999 and August 2008), the majority of hepatitis E cases were diagnosed from September through December [121]. In China, the highest incidence rate of hepatitis E in patients from Wuhan Tongji Hospital (between 2007 and 2008) was observed from January through March [122]. Further studies are needed in order to elucidate the seasonality of HEV.

\section{HEV Infection in Developing Countries}

In developing countries of Asia, Africa and Latin America, HEV infection is considered to be a major cause of viral hepatitis [1,45-47], and occur either in the epidemic or sporadic form $[2,5,6,43,45-47,59,61,74,75]$. The seroprevalence of IgG antibody to HEV in these areas is high, and can exceed 70\% in Egypt [123]. The prevalence of hepatitis E cases in hospital-based studies is also high, and can exceed 37\% in South Asia [1, 45-47]. During hepatitis $\mathrm{E}$ outbreaks, the attack rate varied from 0.3 to $25 \%[2,5,43,61,74,124]$. The symptomatic attack rate in pregnant women in general is high $[2,5,45-47,61]$ and can reach up to $81 \%$ [5].

The majority of the HEV infections in developing countries are subclinical in presentation, with an estimated two to five times greater frequency compared to symptomatic infections for both sporadic and epidemic cases $[61,120,125]$. In addition, the frequency of symp- tomatic infection appears to be higher in men than in women [126]. The first documented outbreak (based on a retrospective study) of hepatitis E occurred in 1955 in New Delhi, India, following faecal contamination of the drinking water supply system by the floods of the Yamuna river [8]. During this epidemic, over 29,000 cases of jaundice were recorded, representing nearly $2 \%$ of the population affected [8]. Since then, numerous other outbreaks of hepatitis $\mathrm{E}$ have been reported, especially in Asia and in Africa $[2,4-7,43,59,74,75,124]$. The most recent hepatitis $E$ outbreaks have occurred on the African continent, especially in Uganda $(>10,196$ hepatitis E cases and 160 deaths recorded in the Kitgum district between October 2007 and June 2009) [5], Sudan (2,621 hepatitis $E$ cases with a case-fatality rate of $1.7 \%$ recorded in a refugee camp in Darfur between July and December 2004) [61] and Central African Republic (222 hepatitis E cases and four deaths recorded in the Begoua district between July 2 and October 2002) [2].

The population mostly affected by HEV infection in developing countries is composed of young adults, men, patients with chronic liver diseases and pregnant women $[5,43,45-47,61,74,122]$. The mortality rate is estimated to be less than $4 \%$ in the general population $[2,43,61$, $124]$, exceeding $20 \%$ in pregnant women $[5,46,47,61]$ and in patients with chronic liver diseases $[122,127]$. The reasons for the higher mortality in pregnant women remain unknown. Immunological and hormonal factors have been hypothesized to explain the pathogenesis of $\mathrm{HEV}$ infection during pregnancy $[128,129]$.

\section{HEV Infection in Developed Countries}

In developed countries, hepatitis E cases usually occur sporadically $[14,18,19,21-23,60]$, although clusters of acute hepatitis E cases have been reported [24, 62, 87]. The high prevalence rates of on-going HEV infection (which can reach up to 1\%) and of anti-HEV antibody prevalence in blood donors suggest that HEV is responsible for several cases of subclinical HEV infections in industrialized countries $[99,107,109,130]$. For instance, in the UK it has been estimated in a study conducted by Ijaz et al. [131] that 60,000 hepatitis E cases occur per year.

Until the end of the 1990s, hepatitis E in developed countries was considered to be an imported disease from HEV hyperendemic areas [13]. However, HEV has emerged (especially in Europe and Japan) over the past decade as a significant cause of non-travel-associated acute hepatitis $[14,18-20,22,23,60,67,132]$. In some countries, the prevalence of autochthonous acute hepatitis $E$ may exceed $16 \%$ in undiagnosed non- $A$, non- $B$, non- 
$\mathrm{C}$ acute hepatitis patients $[14,22,67,132]$. In Japan, the number of reported annual domestic hepatitis E cases increased from 2 in 2000 to 54 in 2006, then plateaued [18]. In England, Dalton et al. [22] observed in Southwest England that the number of hepatitis $\mathrm{E}$ cases increased from 1 in 2000 to 13 in 2006. In France, according to data collected by the National Reference Center of Enterically Transmitted Hepatitis created in 2002, the number of autochthonous hepatitis $\mathrm{E}$ cases increased by a factor of 9 from 2006 through 2010 [133]. For the year 2010 only, 238 autochthonous hepatitis $\mathrm{E}$ cases have been registered by the National Reference Center of Enterically Transmitted Hepatitis [133].

Compared to that of the developing countries, the population mainly affected by HEV infection in developed countries is composed by the elderly, men, immunocompromised patients and patients with chronic liver diseases $[14,18,20-22,100,134]$. The mortality rate in these areas is high and ranges between 2 and 13\% according to the data from hospital-based studies [20-22, 134]. These mortality data should be interpreted with caution, because they are mostly based on the mortality data from patients with clinical symptoms and more severe forms of HEV disease. Striking data have been reported recently by Dalton et al. [135] about the statistically significant independent association between pig meat consumption and mortality from chronic liver diseases in developed countries in the 1990-2000 period. This was revealed by the analysis of data on mortality related to chronic liver diseases, alcohol consumption and hepatitis $\mathrm{B}$ and $\mathrm{C}$ virus seroprevalence for 18 developed countries from 1990 through 2000, and, concurrently, data on national pork and beef consumption. Multivariate regression showed that alcohol, pig meat consumption and hepatitis B virus seroprevalence were independently associated with mortality from chronic liver diseases. A $10-\mathrm{kg}$ increase in national annual average per capita consumption of pig meat was associated with an increase in mortality related to chronic liver diseases that represented 4-5 deaths/100,000 population [135]. The high mortality found in pregnant women in developing countries is not observed in developed countries. To date, to the best of our knowledge, only three autochthonous hepatitis $\mathrm{E}$ cases of genotype 3 have been reported in pregnant women in developed countries [136-138].

The seroprevalence of anti-HEV IgG varies from 2 to over $25 \%$ in developed countries [14, 15, 92-94, 99-101, 131]. In addition, regional differences of HEV seroprevalence have been observed within countries, as shown in the USA [94] and France [92, 139]. In France, seroprevalence of anti-HEV IgG ranged from approximately $3 \%$ in the north to approximately $16 \%$ in the south as assessed using a same serologic assay $[92,139]$. In certain developed countries, the seroprevalence of anti-HEV IgG in the general population is generally much higher than would be expected given the low prevalence of acute symptomatic hepatitis E cases. For instance, in the USA, the seroprevalence of HEV is $21 \%$ in blood donors [94], while only five autochthonous hepatitis $\mathrm{E}$ cases have been reported so far [140].

Contrary to what has been reported in developing countries, since February 2008, several chronic hepatitis E cases and cases of hepatitis E-associated cirrhosis have been described in immunocompromised patients in Europe, including solid-organ transplant recipients (in the majority of cases), HIV-infected patients and patients with haematological diseases [16, 17, 30-33, 141]. All chronic hepatitis $\mathrm{E}$ cases reported so far belonged to genotype $3[16,17,30-33,141]$. Studies are needed to determine whether infection with other HEV genotypes can evolve towards chronic hepatitis.

Possible Impairment of Serologic Assessment of HEV Prevalence and Incidence

There is no gold standard test for the diagnosis of HEV infection. In the setting of routine diagnosis, HEV infection is usually diagnosed using enzyme immunoassays for the detection of specific IgM and IgG antibodies and/or RT-PCR assays for viral RNA detection (standard or, mostly, real-time RT-PCR) $[5,19,20,22,43,44,60,67,108$, $122,132]$. The diagnosis of acute hepatitis $\mathrm{E}$ is based on the detection of IgM antibody to HEV and/or HEV RNA detection (in serum, or faeces when available). No study has performed comparative analysis of all commercial assays that are currently available for the detection of antibodies to HEV. Studies evaluating the performance of some ELISA assays have provided controversial results. Thus, the capability of some assays to detect anti-HEV IgG or IgM antibodies has been found to vary considerably in non-immunocompromised individuals [33, 115]. Bendall et al. [115] reported that anti-HEV IgG testing provided positive results in $98 \%$ of 50 sera from 18 proven cases with the Wantai assay (Beijing, China) versus in 56\% of sera using the Genelabs assay (Genelabs Diagnostics, Singapore). In addition, the Wantai assay resulted in a substantially higher estimate of seroprevalence in blood donors than the test of Genelabs (16.2 vs. 3.6\%). Moreover, anti-HEV IgG were detected in all 12 sera collected $>1$ year after the hepatitis E onset using the Wantai assay, compared with in $50 \%$ of these sera using the Genelabs kit. Dalton et al. [33] also reported that anti-HEV IgG and 
IgM antibodies in a patient chronically infected with HIV (as attested by PCR) were either positive or negative when assessed by the Wantai or the Genelabs assay, respectively. Strikingly, considerable differences were recently pointed out in Southwest France between anti-HEV IgG prevalence measured by different serologic assays. Indeed, antiHEV IgG antibodies were detected in 52 or $16 \%$ of blood donors over the same time period with the Wantai assay or the Adaltis assay, respectively $[92,101]$. In addition, anti-HEV IgG prevalence among patients who underwent haematopoietic stem cell transplantation was 36 and $12 \%$ using the Wantai assay or the Adaltis assay (Ingen, France), respectively [142]. Besides, a progressive decrease of antiHEV IgG over time, and rapid HEV seroreversion in some cases have been reported [34, 117-119]. Thus, Khuroo et al. [117] reported that anti-HEV IgG remained detectable in around half of patients over a 14 -year period, by performing longitudinal testing on serum samples collected from hepatitis E cases. The specificity of all different serological assays currently used for the detection of antibody to HEV has not been evaluated. Commercial ELISA HEV kits from Adaltis and MP Diagnostics available on the market showed a fairly good sensitivity and an excellent specificity, but specificity was assessed using serum samples from blood donors and not samples collected from patients with different pathologies, including patients presenting infectious diseases or increased levels of transaminases [115, 143].

\section{HEV Infection in Other Mammals}

The major animal reservoir for HEV appears to be pigs, although the presence of HEV RNA has been reported in wild boars, deer, rabbits, rats, cows, sheep, bats and mongooses [14, 15, 25-27, 48, 132, 144-146]. HEV infection is ubiquitous in pigs worldwide $[14,15,25,26$, 28 ] and the proportion of farms with at least 1 pig found positive for anti-HEV antibodies and/or HEV RNA can reach up to $100 \%$ in some studies $[48,147]$. The oldest samples from pigs tested to date show that HEV has been circulating in the population of pigs in Spain and India since at least 1985 [148, 149]. Pigs are usually HEV RNApositive when they are young (2-3 months), but high prevalence of HEV RNA (reaching 41\%) have also been found in pigs at the age ( 6 months) at which they are slaughtered $[15,25,28,147]$. Similarly, anti-HEV antibody detection in pigs varies with age [48, 52, 147]. Most pigs under two months of age are anti-HEV-negative, while the majority of pigs older than 3 months are seropositive $[48,52,147]$. In wild boars (Europe, Japan and Australia), the prevalence of anti-HEV antibodies ranges from 9 to $43 \%$ and that of HEV RNA ranges from 3 to $25 \%[27,48,146,150]$. Anti-HEV IgG was detected in $2-35 \%$ of deer in Japan [48] and 5\% of deer in the Netherlands [146]. The prevalence of HEV RNA in deer was $15 \%$ in red deer in the Netherlands [146] and 34\% in roe deer in Hungary [132]. In Japan, the seroprevalence of anti-HEV IgG antibodies in mongooses ranged from 8 to $21 \%[145,151]$. In rats, anti-HEV antibodies have been detected in animals captured in Germany [152], Japan [153], Vietnam [154] and USA [155]. The prevalence of anti-HEV IgG antibodies in rats is high and ranged from 21 to $84 \%$ [152-155] and that of HEV RNA ranged from 0.7 to $18 \%$ [152-154]. Anti-HEV IgM have been detected in $4 \%(5 / 139)$ of wild rats trapped in Vietnam [154]. Little is known about the HEV infection in rabbits and only 3 independent studies have been conducted so far $[144,156$, 157]. In Virginia, USA, HEV RNA was detected in $22 \%$ $(19 / 85)$ of rabbits and anti-HEV antibodies was detected in $36 \%(31 / 85)$ [156]. In China, the overall prevalence of anti-HEV antibody in rabbits ranged from 15 to $57 \%$ and that of HEV RNA ranged from 2 to approximately $8 \%$ $[144,157]$. In addition, a high prevalence of anti-HEV antibodies was detected in various other mammalian groups, including cattle, dogs, cats, horses, goats [48, 81] and in non-human primates [158].

\section{HEV Vaccine}

Since all HEV strains belong to the same serotype [40], a hepatitis E vaccine that shows efficacy to one HEV genotype may be able to provide protection against other genotypes of HEV [159, 160]. Two recombinant hepatitis E vaccines produced with a genotype $1 \mathrm{HEV}$ strain showed promising results concerning the prevention of hepatitis E in humans [161, 162]. The phase III clinical trial of the first vaccine, HEV 239 (expressed in Escherichia coli), has been completed in healthy men and nonpregnant women aged 16-65 years from Jiangsu Province, China [161]. The HEV 239 vaccine was well tolerated and effective in preventing new HEV infections. Three doses ( $30 \mu \mathrm{g}$ per dose) of this vaccine administered intramuscularly at 0, 1 and 6 months were $100 \%$ (95\% CI, 72.1-100.0) efficacious in 48,693 vaccinated persons, 1 year after receiving the third dose [161]. In comparison, 15 of 48,663 individuals who received the placebo (hepatitis $B$ vaccine) developed hepatitis E [161]. Of note, the HEV 239 vaccine has recently (in 2012) been approved for marketing in China [163]. The second vaccine, named rHEV, was produced in insect cells (Spodoptera frugiper- 
da) and its safety and efficacy has been evaluated in a study conducted in Nepal [162]. The rHEV vaccine was well tolerated, and the efficacy of a three-dose vaccination (intramuscular administration of $20 \mu \mathrm{g}$ per dose at months 0,1 and 6) was $95.5 \%(95 \% \mathrm{CI}, 85.6-98.6)$ in a group of volunteers from the Nepalese army [162]. Two years after the administration of the third dose of the rHEV vaccine, the efficacy of the vaccine was only $56.3 \%$, suggesting the necessity to evaluate the maximum duration of protection afforded by the rHEV vaccine [162]. Although the efficacy and safety of the rHEV vaccine has been proven, there are limitations of the study that need to be addressed. The majority of the study participants were men (>99\%) with a mean age of 25.2 years (standard deviation 6.25). The efficacy of the rHEV vaccine for the prevention of asymptomatic HEV infection was not assessed because the endpoint was clinical disease confirmed by laboratory diagnosis of HEV. Of note, a preclinical study conducted in monkeys using the rHEV vaccine showed that this vaccine can protect all monkeys tested against the hepatitis E disease but only partially protected against HEV infection [160]. The use and efficacy of these vaccines can be questioned in immunocompromised patients, as post-exposure prophylaxis in order to determine whether they may be used to control hepatitis E outbreaks, and in the porcine reservoir. The maximum duration of protection afforded by the two hepatitis $E$ vaccines needs to be determined. Finally, a major issue to be addressed is related to obtaining of funding to implement $\mathrm{HEV}$ vaccine strategies for developing countries where HEV is hyperendemic.

\section{Conclusion}

HEV has unveiled a new face over the last decade. The data reviewed here show that HEV undoubtedly has its place alongside other hepatitis viruses $A, B$ and $C$, and the delta agent as one of epidemiological and clinical significance. In developed countries this virus is no more an anecdotal agent responsible for acute hepatitis imported from hyperendemic geographical areas. Therefore, physicians should consider HEV infection as a possible aetiology when facing acute hepatitis. The emergence of chronic hepatitis E and cirrhosis in solid-organ transplant recipients in Europe during the last 5 years has promoted the use of drugs for HEV eradication. The efficacy of pegylated interferon-alpha [141] and of ribavirin, which is an antiviral drug with broad-spectrum activity against several DNA and RNA viruses, has already been evaluated in France in this special population [31, 164]. Fortunately, these drugs, especially ribavirin, have shown promising results.

Our knowledge on the epidemiology of HEV in developed countries has certainly improved considerably (fig. 3), although this should not obscure the fact that a specific route of HEV transmission is identified in a minority of HEV infections. Implementing hospital-based surveillance or mandatory notification of $\mathrm{HEV}$ infection, as is the case currently in Germany, China, Australia and Japan $[18,23,165]$, might improve our knowledge of the HEV epidemiology. The porcine reservoir of HEV has been largely described and identified as a source of HEV in Asia and Europe. Measures for the surveillance and control of HEV infections in pigs or pig food items (such as meat) could be implemented to increase food safety. In 2009 , in an attempt to prevent the transmission of HEV through the zoonotic route in France, the French Agency for Food, Environmental and Occupational Health and Safety compelled manufacturers of pig liver sausages to note on the packaging that the sausages should be cooked thoroughly [24]. The emergence of hepatitis E in developed countries must not lead us to forget that the majority of the clinical burden related to HEV stands in developing countries. The availability and efficacy of the HEV vaccines in these HEV hyperendemic areas are important issues. Besides, globalization might enable the worldwide circulation of HEV strains of different genotypes through human travel and migration, and pig international trading. In this view, whether or not HEV genotypes may be associated with different clinical presentation and outcome should be specifically addressed in the future. Also, the reasons for the higher morbidity or mortality associated with HEV infection in some populations (pregnant women, patients with chronic liver diseases, immunocompromised patients) needs to be deciphered. Finally, the accuracy of our assessment of HEV seroprevalence and incidence using currently commercialized serologic assays is not clear. Therefore, studies to assess the performance of all currently available commercial serological assays for the detection of antibodies against HEV are needed.

\section{Acknowledgments}

We are thankful to Clement Soulas for performing drawings for figure 3.

Mamadou Kaba is a recipient of fellowship from Infectiopole Sud, Marseille, France. 


\section{References}

$\checkmark 1$ Purcell RH, Emerson SU: Hepatitis E: an emerging awareness of an old disease. J Hepatol 2008;48:494-503.

-2 Escriba JM, Nakoune E, Recio C, Massamba PM, Matsika-Claquin MD, Goumba C, Rose AM, Nicand E, Garcia E, Leklegban C, Koffi B: Hepatitis E, Central African Republic. Emerg Infect Dis 2008;14:681-683.

$\checkmark 3$ Verma V, Arankalle VA: Hepatitis E virusbased evaluation of a virion concentration method and detection of enteric viruses in environmental samples by multiplex nested RTPCR. J Appl Microbiol 2010;108:1630-1641.

$\checkmark 4$ Howard CM, Handzel T, Hill VR, Grytdal SP, Blanton C, Kamili S, Drobeniuc J, Hu D, Teshale E: Novel risk factors associated with hepatitis $\mathrm{E}$ virus infection in a large outbreak in northern Uganda: results from a case-control study and environmental analysis. Am J Trop Med Hyg 2010;83:1170-1173.

5 Teshale EH, Howard CM, Grytdal SP, Handzel TR, Barry V, Kamili S, Drobeniuc J, Okware S, Downing R, Tappero JW, Bakamutumaho B, Teo CG, Ward JW, Holmberg SD, $\mathrm{Hu}$ DJ: Hepatitis E epidemic, Uganda. Emerg Infect Dis 2010;16:126-129.

-6 Velazquez O, Stetler HC, Avila C, Ornelas G, Alvarez C, Hadler SC, Bradley DW, Sepulveda J: Epidemic transmission of enterically transmitted non-A, non-B hepatitis in Mexico, 1986-1987. JAMA 1990;263:3281-3285.

$>7$ Khuroo MS: Study of an epidemic of non-A, non-B hepatitis. Possibility of another human hepatitis virus distinct from post-transfusion non-A, non-B type. Am J Med 1980; 68:818-824.

$>8$ Wong DC, Purcell RH, Sreenivasan MA, Prasad SR, Pavri KM: Epidemic and endemic hepatitis in India: evidence for a non-A, non-B hepatitis virus aetiology. Lancet 1980; 2:876-879.

$>9$ Arankalle VA, Chadha MS, Tsarev SA, Emerson SU, Risbud AR, Banerjee K, Purcell $\mathrm{RH}$ : Seroepidemiology of water-borne hepatitis in India and evidence for a third enterically-transmitted hepatitis agent. Proc Natl Acad Sci USA 1994;91:3428-3432.

10 Skidmore SJ, Yarbough PO, Gabor KA, Reyes GR: Hepatitis E virus: the cause of a waterbourne hepatitis outbreak. J Med Virol 1992;37:58-60.

-11 Balayan MS, Andjaparidze AG, Savinskaya SS, Ketiladze ES, Braginsky DM, Savinov AP, Poleschuk VF: Evidence for a virus in non-A, non-B hepatitis transmitted via the fecaloral route. Intervirology 1983;20:23-31.

$\checkmark 12$ Reyes GR, Purdy MA, Kim JP, Luk KC, Young LM, Fry KE, Bradley DW: Isolation of a cDNA from the virus responsible for enterically transmitted non-A, non-B hepatitis. Science 1990;247:1335-1339.

13 Balayan MS: Epidemiology of hepatitis E virus infection. J Viral Hepat 1997;4:155-165.
14 Lewis HC, Wichmann O, Duizer E: Transmission routes and risk factors for autochthonous hepatitis E virus infection in Europe: a systematic review. Epidemiol Infect 2010;138:145-166.

15 Wilhelm BJ, Rajic A, Greig J, Waddell L, Trottier G, Houde A, Harris J, Borden LN, Price C: A systematic review/meta-analysis of primary research investigating swine, pork or pork products as a source of zoonotic hepatitis E virus. Epidemiol Infect 2011; 139:1127-1144.

16 Kamar N, Selves J, Mansuy JM, Ouezzani L, Peron JM, Guitard J, Cointault O, Esposito L, Abravanel F, Danjoux M, Durand D, Vinel JP, Izopet J, Rostaing L: Hepatitis E virus and chronic hepatitis in organ-transplant recipients. N Engl J Med 2008;358:811-817.

17 Gerolami R, Moal V, Colson P: Chronic hepatitis $\mathrm{E}$ with cirrhosis in a kidney-transplant recipient. N Engl J Med 2008;358:859-860.

18 Miyamura T: Hepatitis E virus infection in developed countries. Virus Res 2011;161:40 46.

19 Colson P, Moal V, Motte A, Borentain P, Henry M, Dhiver C, Ressiot E, Garcia S, Brouqui P, Tamalet C, Gerolami R: 39 PCRdocumented cases of acute or chronic hepatitis E over a 2-year period in Marseilles, South-eastern France. Hepatology 2008;48: 1185A-1186A.

20 Renou C, Moreau X, Pariente A, Cadranel JF, Maringe E, Morin T, Causse X, Payen JL, Izopet J, Nicand E, Bourliere M, Penaranda G, Hardwigsen J, Gerolami R, Peron JM, Pavio N: A national survey of acute hepatitis E in France. Aliment Pharmacol Ther 2008; 27:1086-1093.

21 Mansuy JM, Abravanel F, Miedouge M, Mengelle C, Merviel C, Dubois M, Kamar N, Rostaing L, Alric L, Moreau J, Peron JM, Izopet J: Acute hepatitis $\mathrm{E}$ in south-west France over a 5-year period. J Clin Virol 2009;44:74-77.

22 Dalton HR, Stableforth W, Thurairajah P, Hazeldine S, Remnarace R, Usama W, Farrington L, Hamad N, Sieberhagen C, Ellis V, Mitchell J, Hussaini SH, Banks M, Ijaz S, Bendall RP: Autochthonous hepatitis E in Southwest England: natural history, complications and seasonal variation, and hepatitis E virus IgG seroprevalence in blood donors, the elderly and patients with chronic liver disease. Eur J Gastroenterol Hepatol 2008; 20:784-790.

23 Wichmann O, Schimanski S, Koch J, Kohler M, Rothe C, Plentz A, Jilg W, Stark K: Phylogenetic and case-control study on hepatitis $\mathrm{E}$ virus infection in Germany. J Infect Dis 2008;198:1732-1741.

-24 Colson P, Borentain P, Queyriaux B, Kaba M, Moal V, Gallian P, Heyries L, Raoult D, Gerolami R: Pig liver sausage as a source of hepatitis E virus transmission to humans. J Infect Dis 2010;202:825-834.
25 Kaba M, Davoust B, Marie JL, Barthet M, Henry M, Tamalet C, Raoult D, Colson P: Frequent transmission of hepatitis $\mathrm{E}$ virus among piglets in farms in Southern France. J Med Virol 2009;81:1750-1759.

26 Kaba M, Colson P, Musongela JP, Tshilolo L, Davoust B: Detection of hepatitis E virus of genotype 3 in a farm pig in Kinshasa (Democratic Republic of the Congo). Infect Genet Evol 2010;10:154-157.

27 Kaba M, Davoust B, Marie JL, Colson P: Detection of hepatitis E virus in wild boar (Sus scrofa) livers. Vet J 2010;186:259-261.

28 Kaba M, Davoust B, Cabre O, Colson P: Hepatitis Evirus genotype $3 \mathrm{f}$ in pigs in New Caledonia. Aust Vet J 2011;89:496-499.

29 Li TC, Chijiwa K, Sera N, Ishibashi T, Etoh Y, Shinohara Y, Kurata Y, Ishida M, Sakamoto S, Takeda N, Miyamura T: Hepatitis E virus transmission from wild boar meat. Emerg Infect Dis 2005;11:1958-1960.

30 Colson P, Dhiver C, Poizot-Martin I, Tamalet C, Gerolami R: Acute and chronic hepatitis $\mathrm{E}$ in patients infected with human immunodeficiency virus. J Viral Hepat 2011;18: 227-228.

31 Mallet V, Nicand E, Sultanik P, Chakvetadze C, Tesse S, Thervet E, Mouthon L, Sogni P, Pol S: Brief communication: case reports of ribavirin treatment for chronic hepatitis $\mathrm{E}$. Ann Intern Med 2010;153:85-89.

32 Colson P, Kaba M, Moreau J, Brouqui P: Hepatitis $\mathrm{E}$ in an $\mathrm{HIV}$-infected patient. J Clin Virol 2009;45:269-271.

33 Dalton HR, Bendall RP, Keane FE, Tedder RS, Ijaz S: Persistent carriage of hepatitis E virus in patients with HIV infection. N Engl J Med 2009;361:1025-1027.

34 Kaba M, Richet H, Ravaux I, Moreau J, Poizot-Martin I, Motte A, Nicolino-Brunet C, Dignat-George F, Menard A, Dhiver C, Brouqui P, Colson P: Hepatitis E virus infection in patients infected with the human immunodeficiency virus. J Med Virol 2011;83: 1704-1716.

35 Emerson SU, Anderson D, Arankalle A, Meng XJ, Purdy M, Schlauder GG, Tsarev SA: Hepevirus; in Fauquet CM, Mayo MA, Maniloff J, Desselberger U, Ball LA (eds): Virus Taxonomy: The Eighth Report of the International Committee on Taxonomy of Viruses. London, Elsevier, 2005, pp 853-857.

36 Balayan MS: Type E hepatitis: state of the art. Int J Infect Dis 1997;2:113-120.

>37 Koonin EV, Gorbalenya AE, Purdy MA, Rozanov MN, Reyes GR, Bradley DW: Computer-assisted assignment of functional domains in the nonstructural polyprotein of hepatitis E virus: delineation of an additional group of positive-strand RNA plant and animal viruses. Proc Natl Acad Sci USA 1992;89:8259-8263. 
-38 Tam AW, Smith MM, Guerra ME, Huang CC, Bradley DW, Fry KE, Reyes GR: Hepatitis $\mathrm{E}$ virus (HEV): molecular cloning and sequencing of the full-length viral genome. Virology 1991;185:120-131.

-39 Ahmad I, Holla RP, Jameel S: Molecular virology of hepatitis E virus. Virus Res 2011; 161:47-58.

40 Emerson SU, Clemente-Casares P, Moiduddin N, Arankalle VA, Torian U, Purcell RH: Putative neutralization epitopes and broad cross-genotype neutralization of Hepatitis $\mathrm{E}$ virus confirmed by a quantitative cell-culture assay. J Gen Virol 2006;87:697-704.

- 41 Lu L, Li C, Hagedorn CH: Phylogenetic analysis of global hepatitis $\mathrm{E}$ virus sequences: genetic diversity, subtypes and zoonosis. Rev Med Virol 2006; 16:5-36.

-42 Drexler JF, Seelen A, Corman VM, Fumie TA, Cottontail V, Melim ZR, Gloza-Rausch F, Klose SM, du-Sarkodie Y, Oppong SK, Kalko EK, Osterman A, Rasche A, Adam A, Muller MA, Ulrich RG, Leroy EM, Lukashev AN, Drosten C: Bats worldwide carry hepatitis E-related viruses that form a putative novel genus within the family Hepeviridae. J Virol 2012;86:9134-9147.

43 Vivek R, Nihal L, Illiayaraja J, Reddy PK, Sarkar R, Eapen CE, Kang G: Investigation of an epidemic of Hepatitis $\mathrm{E}$ in Nellore in South India. Trop Med Int Health 2010;15: 1333-1339.

-44 Delarocque-Astagneau E, Abravanel F, Moshen A, Le FL, Gad RR, El-Daly M, Ibrahim EM, El-Aidy S, Lashin T, El-Hoseiny M, Izopet J, Mohamed MK, Fontanet A, Abdel HM: Epidemiological and virological characteristics of symptomatic acute hepatitis $\mathrm{E}$ in Greater Cairo, Egypt. Clin Microbiol Infect 2012;18:982-988.

-45 Kumar S, Ratho RK, Chawla YK, Chakraborti A: The incidence of sporadic viral hepatitis in North India: a preliminary study. Hepatobiliary Pancreat Dis Int 2007;6:596-599.

-46 Patra S, Kumar A, Trivedi SS, Puri M, Sarin SK: Maternal and fetal outcomes in pregnant women with acute hepatitis E virus infection. Ann Intern Med 2007;147:28-33.

47 Mamun AM, Rahman S, Khan M, Karim F: HEV infection as an aetiologic factor for acute hepatitis: experience from a tertiary hospital in Bangladesh. J Health Popul Nutr 2009;27:14-19.

-48 Pavio N, Meng XJ, Renou C: Zoonotic hepatitis $\mathrm{E}$ : animal reservoirs and emerging risks. Vet Res 2010;41:46.

49 Colson P, Swiader L, Motte A, Ferretti A, 62 Borentain P, Gérolami R: Circulation of almost genetically-identical hepatitis $\mathrm{E}$ virus of genotype 4 in France. J Clin Virol 2012;55: 181-183.

50 Dalton HR, Fellows HJ, Gane EJ, Wong P, Gerred S, Schroeder B, Croxson MC, Garkavenko O: Hepatitis E in New Zealand. J Gastroenterol Hepatol 2007;22:1236-1240.
51 Hakze-van der Honing RW, van CE, Antonis AF, van der Poel WH: First isolation of hepatitis $\mathrm{E}$ virus genotype 4 in Europe through swine surveillance in the Netherlands and Belgium. PLoS One 2011;6:e22673.

52 Meng XJ, Purcell RH, Halbur PG, Lehman JR, Webb DM, Tsareva TS, Haynes JS, Thacker BJ, Emerson SU: A novel virus in swine is closely related to the human hepatitis E virus. Proc Natl Acad Sci USA 1997;94:98609865.

53 Purdy MA, Khudyakov YE: Evolutionary history and population dynamics of hepatitis E virus. PLoS One 2010;5:e14376.

54 Xia H, Wahlberg N, Belak S, Meng XJ, Liu L: The emergence of genotypes 3 and 4 hepatitis E virus in swine and humans: a phylogenetic perspective. Arch Virol 2011;156:121-124.

55 Wang H, Zhang W, Ni B, Shen H, Song Y, Wang X, Shao S, Hua X, Cui L: Recombination analysis reveals a double recombination event in hepatitis E virus. Virol J 2010;7:129.

56 Moal V, Gerolami R, Colson P: First human case of co-infection with two different subtypes of hepatitis E virus. Intervirology 2012, E-pub ahead of print.

-57 de Deus N, Casas M, Peralta B, Nofrarias M, Pina S, Martin M, Segales J: Hepatitis E virus infection dynamics and organic distribution in naturally infected pigs in a farrow-to-finish farm. Vet Microbiol 2008;132:19-28.

58 Grandadam M, Tebbal S, Caron M, Siriwardana M, Larouze B, Koeck JL, Buisson Y, Enouf V, Nicand E: Evidence for hepatitis E virus quasispecies. J Gen Virol 2004;85: 3189-3194.

59 Corwin AL, Khiem HB, Clayson ET, Pham KS, Vo TT, Vu TY, Cao TT, Vaughn D, Merven J, Richie TL, Putri MP, He J, Graham R, Wignall FS, Hyams KC: A waterborne outbreak of hepatitis $\mathrm{E}$ virus transmission in Southwestern Vietnam. Am J Trop Med Hyg 1996;54:559-562.

60 Borgen K, Herremans T, Duizer E, Vennema H, Rutjes S, Bosman A, de Roda Husman AM, Koopmans M: Non-travel related hepatitis $\mathrm{E}$ virus genotype 3 infections in the Netherlands; a case series 2004-2006. BMC Infect Dis 2008;8:61.

61 Guthmann JP, Klovstad H, Boccia D, Hamid N, Pinoges L, Nizou JY, Tatay M, Diaz F, Moren A, Grais RF, Ciglenecki I, Nicand E, Guerin PJ: A large outbreak of hepatitis E among a displaced population in Darfur, Sudan, 2004: the role of water treatment methods. Clin Infect Dis 2006;42:1685-1691.

62 Matsubayashi K, Kang JH, Sakata H, Takahashi K, Shindo M, Kato M, Sato S, Kato T, Nishimori H, Tsuji K, Maguchi H, Yoshida J, Maekubo H, Mishiro S, Ikeda H: A case of transfusion-transmitted hepatitis $\mathrm{E}$ caused by blood from a donor infected with hepatitis E virus via zoonotic food-borne route. Transfusion 2008;48:1368-1375.
63 Colson P, Coze C, Gallian P, Henry M, De MP, Tamalet C: Transfusion-associated hepatitis E, France. Emerg Infect Dis 2007;13: 648-649.

64 Khuroo MS, Kamili S, Khuroo MS: Clinical course and duration of viremia in vertically transmitted hepatitis E virus (HEV) infection in babies born to HEV-infected mothers. J Viral Hepat 2009;16:519-523.

-65 Kumar RM, Uduman S, Rana S, Kochiyil JK, Usmani A, Thomas L: Sero-prevalence and mother-to-infant transmission of hepatitis $\mathrm{E}$ virus among pregnant women in the United Arab Emirates. Eur J Obstet Gynecol Reprod Biol 2001;100:9-15.

-66 Kumar A, Beniwal M, Kar P, Sharma JB, Murthy NS: Hepatitis E in pregnancy. Int J Gynaecol Obstet 2004;85:240-244.

-67 Romano L, Paladini S, Tagliacarne C, Canuti M, Bianchi S, Zanetti AR: Hepatitis E in Italy: a long-term prospective study. J Hepatol 2011;54:34-40.

68 Somani SK, Aggarwal R, Naik SR, Srivastava S, Naik S: A serological study of intrafamilial spread from patients with sporadic hepatitis E virus infection. J Viral Hepat 2003;10:446449.

69 Siddiqui AR, Jooma RA, Smego RA Jr: Nosocomial outbreak of hepatitis $\mathrm{E}$ infection in Pakistan with possible parenteral transmission. Clin Infect Dis 2005;40:908-909.

70 Neogi DK, Bhattacharya N, De PN, Chakravarti T, Hati AK, Prakash C, Datta KK, Mukherjee KK: An institutional outbreak of hepatitis E - reported first time from Calcutta City. J Commun Dis 1995;27:229-233.

-71 Schlosser B, Stein A, Neuhaus R, Pahl S, Ramez B, Kruger DH, Berg T, Hofmann J: Liver transplant from a donor with occult HEV infection induced chronic hepatitis and cirrhosis in the recipient. J Hepatol 2012;56:500-502.

72 Meng XJ, Halbur PG, Shapiro MS, Govindarajan S, Bruna JD, Mushahwar IK, Purcell RH, Emerson SU: Genetic and experimental evidence for cross-species infection by swine hepatitis E virus. J Virol 1998;72:9714-9721.

73 Hazam RK, Singla R, Kishore J, Singh S, Gupta RK, Kar P: Surveillance of hepatitis E virus in sewage and drinking water in a resettlement colony of Delhi: what has been the experience? Arch Virol 2010;155:1227-1233.

74 Martolia HC, Hutin Y, Ramachandran V, Manickam P, Murhekar M, Gupte M: An outbreak of hepatitis E tracked to a spring in the foothills of the Himalayas, India, 2005. Indian J Gastroenterol 2009;28:99-101.

75 Sarguna P, Rao A, Sudha Ramana KN: Outbreak of acute viral hepatitis due to hepatitis E virus in Hyderabad. Indian J Med Microbiol 2007;25:378-382.

76 El-Esnawy NA, Gamil MA, El-Wakkad AS: Detection of hepatitis E virus in greater Cairo. Two wastewater treatment plants and its prevalence among workers of these plants. J Egypt Public Health Assoc 1998;73:597-619. 
-77 Ceylan A, Ertem M, Ilcin E, Ozekinci T: A special risk group for hepatitis $\mathrm{E}$ infection: Turkish agricultural workers who use untreated waste water for irrigation. Epidemiol Infect 2003;131:753-756.

-78 Kitajima M, Matsubara K, Sour S, Haramoto E, Katayama H, Ohgaki S: First detection of genotype 3 hepatitis E virus RNA in river water in Cambodia. Trans R Soc Trop Med Hyg 2009;103:955-957.

79 Rutjes SA, Lodder WJ, Lodder-Verschoor F, van den Berg HH, Vennema H, Duizer E, Koopmans M, de Roda Husman AM: Sources of hepatitis Evirus genotype 3 in the Netherlands. Emerg Infect Dis 2009;15:381-387.

-80 Clemente-Casares P, Rodriguez-Manzano J, Girones R: Hepatitis E virus genotype 3 and sporadically also genotype 1 circulate in the population of Catalonia, Spain. J Water Health 2009;7:664-673.

-81 Song YJ, Jeong HJ, Kim YJ, Lee SW, Lee JB, Park SY, Song CS, Park HM, Choi IS: Analysis of complete genome sequences of swine hepatitis E virus and possible risk factors for transmission of HEV to humans in Korea. J Med Virol 2010;82:583-591.

-82 Brassard J, Gagne MJ, Genereux M, Cote C: Detection of human food-borne and zoonotic viruses on irrigated, field-grown strawberries. Appl Environ Microbiol 2012;78:37633766.

-83 Galiana C, Fernandez-Barredo S, Garcia A, Gomez MT, Perez-Gracia MT: Occupational exposure to hepatitis E virus (HEV) in swine workers. Am J Trop Med Hyg 2008;78:10121015.

84 Tumerelle E, Domart M: Hepatite E autochtone presummee professionnelle: a propos d'un cas. Arch Mal Prof 2000;61:318-323.

$>85$ Bouwknegt M, Lodder-Verschoor F, van der Poel WH, Rutjes SA, de Roda Husman AM: Hepatitis E virus RNA in commercial porcine livers in the Netherlands. J Food Prot 2007;70:2889-2895.

-86 Feagins AR, Opriessnig T, Guenette DK, Halbur PG, Meng XJ: Inactivation of infectious hepatitis $\mathrm{E}$ virus present in commercial pig livers sold in local grocery stores in the United States. Int J Food Microbiol 2008;123: 32-37.

87 Miyashita K, Kang JH, Saga A, Takahashi K, Shimamura T, Yasumoto A, Fukushima H, Sogabe S, Konishi K, Uchida T, Fujinaga A, Matsui T, Sakurai Y, Tsuji K, Maguchi H, Taniguchi M, Abe N, Fazle Akbar SM, Arai M, Mishiro S: Three cases of acute or fulminant hepatitis E caused by ingestion of pork meat and entrails in Hokkaido, Japan: zoonotic food-borne transmission of hepatitis $\mathrm{E}$ virus and public health concerns. Hepatol Res 2012;42:870-878.
Legrand-Abravanel F, Kamar N, SandresSaune K, Garrouste C, Dubois M, Mansuy JM, Muscari F, Sallusto F, Rostaing L, Izopet J: Characteristics of autochthonous hepatitis E virus infection in solid-organ transplant recipients in France. J Infect Dis 2010;202: 835-844.

89 Surya IG, Kornia K, Suwardewa TG, Mulyanto, Tsuda F, Mishiro S: Serological markers of hepatitis B, C, and E viruses and human immunodeficiency virus type-1 infections in pregnant women in Bali, Indonesia. J Med Virol 2005;75:499-503.

90 Toyoda K, Furusyo N, Takeoka H, Murata M, Sawayama Y, Hayashi J: Epidemiological study of hepatitis E virus infection in the general population of Okinawa, Kyushu, Japan. J Gastroenterol Hepatol 2008;23:18851890.

-91 Colson P, Kaba M, Bernit E, Motte A, Tamalet C: Hepatitis E associated with surgical training on pigs. Lancet 2007;370:935.

92 Mansuy JM, Legrand-Abravanel F, Calot JP, Peron JM, Alric L, Agudo S, Rech H, Destruel F, Izopet J: High prevalence of anti-hepatitis E virus antibodies in blood donors from South West France. J Med Virol 2008;80: 289-293.

93 Christensen PB, Engle RE, Hjort C, Homburg KM, Vach W, Georgsen J, Purcell RH: Time trend of the prevalence of hepatitis $\mathrm{E}$ antibodies among farmers and blood donors: a potential zoonosis in Denmark. Clin Infect Dis 2008;47:1026-1031.

$>94$ Kuniholm MH, Purcell RH, McQuillan GM, Engle RE, Wasley A, Nelson KE: Epidemiology of hepatitis E virus in the United States: results from the Third National Health and Nutrition Examination Survey, 1988-1994. J Infect Dis 2009;200:48-56.

95 Ekser B, Ezzelarab M, Hara H, van der Windt DJ, Wijkstrom M, Bottino R, Trucco M, Cooper DK: Clinical xenotransplantation: the next medical revolution? Lancet 2012;379: 672-683.

96 Said B, Ijaz S, Kafatos G, Booth L, Thomas HL, Walsh A, Ramsay M, Morgan D: Hepatitis E outbreak on cruise ship. Emerg Infect Dis 2009; 15:1738-1744.

$\$ 97$ Li TC, Miyamura T, Takeda N: Detection of hepatitis E virus RNA from the bivalve Yamato-Shijimi (Corbicula japonica) in Japan. Am J Trop Med Hyg 2007;76:170-172.

98 Arankalle VA, Chobe LP: Retrospective analysis of blood transfusion recipients: evidence for post-transfusion hepatitis E. Vox Sang 2000;79:72-74.

99 Sakata H, Matsubayashi K, Takeda H, Sato S, Kato T, Hino S, Tadokoro K, Ikeda H: A nationwide survey for hepatitis E virus prevalence in Japanese blood donors with elevated alanine aminotransferase. Transfusion 2008;48:2568-2576.
100 Takeda H, Matsubayashi K, Sakata H, Sato S, Kato T, Hino S, Tadokoro K, Ikeda H: A nationwide survey for prevalence of hepatitis $\mathrm{E}$ virus antibody in qualified blood donors in Japan. Vox Sang 2010;99:307-313.

101 Mansuy JM, Bendall R, Legrand-Abravanel F, Saune K, Miedouge M, Ellis V, Rech H, Destruel F, Kamar N, Dalton HR, Izopet J: Hepatitis E virus antibodies in blood donors, France. Emerg Infect Dis 2011;17: 2309-2312.

102 Khuroo MS, Kamili S, Yattoo GN: Hepatitis $\mathrm{E}$ virus infection may be transmitted through blood transfusions in an endemic area. J Gastroenterol Hepatol 2004;19:778784.

103 Nicand E, Grandadam M, Teyssou R, Rey JL, Buisson Y: Viraemia and faecal shedding of $\mathrm{HEV}$ in symptom-free carriers. Lancet 2001;357:68-69.

104 Adlhoch C, Kaiser M, Pauli G, Koch J, Meisel H: Indigenous hepatitis E virus infection of a plasma donor in Germany. Vox Sang 2009;97:303-308.

105 Renou C, Pariente A, Cadranel JF, Nicand E, Pavio N: Clinically silent forms may partly explain the rarity of acute cases of autochthonous genotype $3 \mathrm{c}$ hepatitis $\mathrm{E}$ infection in France. J Clin Virol 2011;51:139141

106 Guo QS, Yan Q, Xiong JH, Ge SX, Shih JW, Ng MH, Zhang J, Xia NS: Prevalence of hepatitis $\mathrm{E}$ virus in Chinese blood donors. J Clin Microbiol 2010;48:317-318.

107 Baylis SA, Gartner T, Nick S, Ovemyr J, Blumel J: Occurrence of hepatitis E virus RNA in plasma donations from Sweden, Germany and the United States. Vox Sang 2012; 103:89-90.

108 Baylis SA, Hanschmann KM, Blumel J, Nubling CM: Standardization of hepatitis E virus (HEV) nucleic acid amplification technique-based assays: an initial study to evaluate a panel of HEV strains and investigate laboratory performance. J Clin Microbiol 2011;49:1234-1239.

109 Ijaz S, Szypulska R, Tettmar KI, Kitchen A, Tedder RS: Detection of hepatitis E virus RNA in plasma mini-pools from blood donors in England. Vox Sang 2012;102:272.

110 Hosseini-Moghaddam SM, Zarei A, Alavian SM, Mansouri M: Hepatitis E virus infection: a general review with a focus on hemodialysis and kidney transplant patients. Am J Nephrol 2010;31:398-407.

111 Toyoda H, Honda T, Hayashi K, Katano Y, Goto H, Kumada T, Takahashi K, Abe N, Mishiro S, Takamatsu J: Prevalence of hepatitis E virus IgG antibody in Japanese patients with hemophilia. Intervirology 2008 51:21-25. 
$\checkmark 112$ Kaba M, Brouqui P, Richet H, Badiaga S, 124 Swain SK, Baral P, Hutin YJ, Rao TV, Gallian P, Raoult D, Colson P: Hepatitis E virus infection in sheltered homeless persons, France. Emerg Infect Dis 2010;16: $1761-1763$.

-113 Kasorndorkbua C, Thacker BJ, Halbur PG, Guenette DK, Buitenwerf RM, Royer RL, Meng XJ: Experimental infection of pregnant gilts with swine hepatitis E virus. Can J Vet Res 2003;67:303-306.

- 114 Chibber RM, Usmani MA, Al-Sibai MH: Should HEV infected mothers breast feed? Arch Gynecol Obstet 2004;270:15-20.

- 115 Bendall R, Ellis V, Ijaz S, Ali R, Dalton H: A comparison of two commercially available anti-HEV IgG kits and a re-evaluation of anti-HEV IgG seroprevalence data in developed countries. J Med Virol 2010;82:799_ 805.

-116 Drobeniuc J, Meng J, Reuter G, GreeneMontfort T, Khudyakova N, Dimitrova Z, Kamili S, Teo CG: Serologic assays specific to immunoglobulin $\mathrm{M}$ antibodies against hepatitis E virus: pangenotypic evaluation of performances. Clin Infect Dis 2010; 51:e24-e27.

- 117 Khuroo MS, Kamili S, Dar MY, Moecklii R, Jameel S: Hepatitis E and long-term antibody status. Lancet 1993;341:1355.

-118 Myint KS, Endy TP, Shrestha MP, Shrestha SK, Vaughn DW, Innis BL, Gibbons RV, Kuschner RA, Seriwatana J, Scott RM: Hepatitis E antibody kinetics in Nepalese patients. Trans R Soc Trop Med Hyg 2006;100: 938-941.

-119 Li RC, Ge SX, Li YP, Zheng YJ, Nong Y, Guo QS, Zhang J, Ng MH, Xia NS: Seroprevalence of hepatitis $\mathrm{E}$ virus infection, rural southern People's Republic of China. Emerg Infect Dis 2006;12:1682-1688.

$>120$ Bryan JP, Iqbal M, Tsarev S, Malik IA, Duncan JF, Ahmed A, Khan A, Khan A, Rafiqui AR, Purcell RH, Legters LJ: Epidemic of hepatitis E in a military unit in Abbotrabad, Pakistan. Am J Trop Med Hyg 2002;67: 662-668.

-121 Inoue J, Ueno Y, Nagasaki F, Akahane T, Fukushima K, Kogure T, Kondo Y, Kakazu E, Tamai K, Kido O, Nakagome Y, Ninomiya M, Obara N, Wakui Y, Takahashi M, Okamoto H, Shimosegawa T: Sporadic acute hepatitis E occurred constantly during the last decade in northeast Japan. J Gastroenterol 2009;44:329-337.

-122 Zhang S, Wang J, Yuan Q, Ge S, Zhang J, Xia $\mathrm{N}$, Tian D: Clinical characteristics and risk factors of sporadic Hepatitis E in central China. Virol J 2011;8:152.

123 Fix AD, Abdel-Hamid M, Purcell RH, Shehata MH, bdel-Aziz F, Mikhail N, el SH, Nafeh M, Habib M, Arthur RR, Emerson SU, Strickland GT: Prevalence of antibodies to hepatitis E in two rural Egyptian communities. Am J Trop Med Hyg 2000;62: 519-523. Murhekar M, Gupte MD: A hepatitis E outbreak caused by a temporary interruption in a municipal water treatment system, Baripada, Orissa, India, 2004. Trans R Soc Trop Med Hyg 2010;104:66-69.

125 Clayson ET, Vaughn DW, Innis BL, Shrestha MP, Pandey R, Malla DB: Association of hepatitis $\mathrm{E}$ virus with an outbreak of hepatitis at a military training camp in Nepal. J Med Virol 1998;54:178-182.

126 Aggarwal R, Kumar R, Pal R, Naik S, Semwal SN, Naik SR: Role of travel as a risk factor for hepatitis E virus infection in a disease-endemic area. Indian J Gastroenterol 2002;21:14-18.

127 Zhang X, Ke W, Xie J, Zhao Z, Xie D, Gao $\mathrm{Z}$ : Comparison of effects of hepatitis $\mathrm{E}$ or A viral superinfection in patients with chronic hepatitis B. Hepatol Int 2010;4:615-620.

128 Bose PD, Das BC, Kumar A, Gondal R, Kumar D, Kar P: High viral load and deregulation of progesterone receptor signaling pathway: association with hepatitis E related poor pregnancy outcome. J Hepatol 2011;54:1107-1113.

129 Navaneethan U, Al MM, Shata MT: Hepatitis $\mathrm{E}$ and pregnancy: understanding the pathogenesis. Liver Int 2008;28:1190-1199.

130 Baylis SA, Koc O, Nick S, Blumel J: Widespread distribution of hepatitis E virus in plasma fractionation pools. Vox Sang 2012; 102:182-183.

131 Ijaz S, Vyse AJ, Morgan D, Pebody RG, Tedder RS, Brown D: Indigenous hepatitis Evirus infection in England: more common than it seems. J Clin Virol 2009;44:272-276.

132 Reuter G, Fodor D, Forgach P, Katai A, Szucs G: Characterization and zoonotic potential of endemic hepatitis E virus (HEV) strains in humans and animals in Hungary. J Clin Virol 2009;44:277-281.

133 Bouquet J, Tesse S, Lunazzi A, Eloit M, Rose N, Nicand E, Pavio N: Close similarity between sequences of hepatitis E virus recovered from humans and swine, France, 20082009. Emerg Infect Dis 2011;17:2018-2025.

134 Peron JM, Bureau C, Poirson H, Mansuy JM, Alric L, Selves J, Dupuis E, Izopet J, Vinel JP: Fulminant liver failure from acute autochthonous hepatitis E in France: description of seven patients with acute hepatitis E and encephalopathy. J Viral Hepat 2007;14:298-303.

135 Dalton HR, Bendall RP, Pritchard C, Henley W, Melzer D: National mortality rates from chronic liver disease and consumption of alcohol and pig meat. Epidemiol Infect 2010;138:174-182.

136 Anty R, Ollier L, Peron JM, Nicand E, Cannavo I, Bongain A, Giordanengo V, Tran A: First case report of an acute genotype 3 hepatitis $\mathrm{E}$ infected pregnant woman living in South-Eastern France. J Clin Virol 2012;54: 76-78.
37 Andersson MI, Hughes J, Gordon FH, Ijaz S, Donati M: Of pigs and pregnancy. Lancet 2008;372:1192.

138 Aikawa T, Yamagata K, Miyamoto K, Tsuda F, Takahashi M, Okamoto $\mathrm{H}$ : A first case of pregnant woman who contracted infection of indigenous genotype 3 hepatitis E virus in Japan. Kanzo 2009;50:163-165.

139 Boutrouille A, Bakkali-Kassimi L, Cruciere C, Pavio N: Prevalence of anti-hepatitis E virus antibodies in French blood donors. J Clin Microbiol 2007;45:2009-2010.

140 Curry JA, Adams N, Crum-Cianflone NF: Acute hepatitis E virus infection in an HIVinfected person in the United States. Ann Intern Med 2009;150:226-227.

141 Pischke S, Wedemeyer H: Chronic hepatitis E in liver transplant recipients: a significant clinical problem? Minerva Gastroenterol Dietol 2010;56:121-128.

142 Abravanel F, Mansuy JM, Huynh A, Kamar N, Alric L, Peron JM, Recher C, Izopet J: Low risk of hepatitis E virus reactivation after haematopoietic stem cell transplantation. J Clin Virol 2012;54:152-155.

143 Legrand-Abravanel F, Thevenet I, Mansuy JM, Saune K, Vischi F, Peron JM, Kamar N, Rostaing L, Izopet J: Good performance of immunoglobulin $\mathrm{M}$ assays in diagnosing genotype 3 hepatitis E virus infections. Clin Vaccine Immunol 2009;16:772-774.

144 Zhao C, Ma Z, Harrison TJ, Feng R, Zhang C, Qiao Z, Fan J, Ma H, Li M, Song A, Wang $\mathrm{Y}$ : A novel genotype of hepatitis $\mathrm{E}$ virus prevalent among farmed rabbits in China. J Med Virol 2009;81:1371-1379.

145 Nakamura M, Takahashi K, Taira K, Taira M, Ohno A, Sakugawa H, Arai M, Mishiro S: Hepatitis E virus infection in wild mongooses of Okinawa, Japan: demonstration of anti-HEV antibodies and a full-genome nucleotide sequence. Hepatol Res 2006;34: 137-140.

146 Rutjes SA, Lodder-Verschoor F, Lodder WJ, van der Giessen J, Reesink H, Bouwknegt M, de Roda Husman AM: Seroprevalence and molecular detection of hepatitis E virus in wild boar and red deer in the Netherlands. J Virol Methods 2010;168:197-206.

147 Nakai I, Kato K, Miyazaki A, Yoshii M, Li TC, Takeda N, Tsunemitsu H, Ikeda H: Different fecal shedding patterns of two common strains of hepatitis E virus at three Japanese swine farms. Am J Trop Med Hyg 2006;75:1171-1177.

148 Casas M, Pujols J, Rosell R, de Deus N, Peralta B, Pina S, Casal J, Martin M: Retrospective serological study on hepatitis $\mathrm{E}$ infection in pigs from 1985 to 1997 in Spain. Vet Microbiol 2009; 135:248-252.

149 Arankalle VA, Chobe LP, Walimbe AM, Yergolkar PN, Jacob GP: Swine HEV infection in south India and phylogenetic analysis (1985-1999). J Med Virol 2003;69:391396. 
150 Chandler JD, Riddell MA, Li F, Love RJ, Anderson DA: Serological evidence for swine hepatitis E virus infection in Australian pig herds. Vet Microbiol 1999;68:95-105.

151 Li TC, Saito M, Ogura G, Ishibashi O, Miyamura T, Takeda N: Serologic evidence for hepatitis $\mathrm{E}$ virus infection in mongoose. Am J Trop Med Hyg 2006;74:932-936.

$>152$ Johne R, Dremsek P, Kindler E, Schielke A, Plenge-Bonig A, Gregersen $\mathrm{H}$, Wessels $\mathrm{U}$, Schmidt K, Rietschel W, Groschup MH, Guenther S, Heckel G, Ulrich RG: Rat hepatitis E virus: Geographical clustering within Germany and serological detection in wild Norway rats (Rattus norvegicus). Infect Genet Evol 2012;12:947-956.

153 Kanai Y, Miyasaka S, Uyama S, Kawami S, Kato-Mori Y, Tsujikawa M, Yunoki M, Nishiyama S, Ikuta K, Hagiwara K: Hepatitis E virus in Norway rats (Rattus norvegicus) captured around a pig farm. BMC Res Notes 2012;5:4.

154 Li TC, Yoshimatsu K, Yasuda SP, Arikawa J, Koma T, Kataoka M, Ami Y, Suzaki Y, Mai le TQ, Hoa NT, Yamashiro T, Hasebe F, Takeda N, Wakita T: Characterization of self-assembled virus-like particles of rat hepatitis $\mathrm{E}$ virus generated by recombinant baculoviruses. J Gen Virol 2011;92:28302837.
155 Kabrane-Lazizi Y, Fine JB, Elm J, Glass GE, Higa H, Diwan A, Gibbs CJ Jr, Meng XJ, Emerson SU, Purcell RH: Evidence for widespread infection of wild rats with hepatitis E virus in the United States. Am J Trop Med Hyg 1999;61:331-335.

156 Cossaboom CM, Cordoba L, Dryman BA, Meng XJ: Hepatitis E virus in rabbits, Virginia, USA. Emerg Infect Dis 2011;17:20472049.

157 Geng Y, Zhao C, Song A, Wang J, Zhang X, Harrison TJ, Zhou Y, Wang W, Wang Y: The serological prevalence and genetic diversity of hepatitis $\mathrm{E}$ virus in farmed rabbits in China. Infect Genet Evol 2011;11: 476-482.

158 Yamamoto H, Li TC, Koshimoto C, Ito K, Kita M, Miyashita N, Arikawa J, Yagami K, Asano M, Tezuka H, Suzuki N, Kurosawa T, Shibahara T, Furuya M, Mohri S, Sato H, Ohsawa K, Ibuki K, Takeda N: Serological evidence for hepatitis $\mathrm{E}$ virus infection in laboratory monkeys and pigs in animal facilities in Japan. Exp Anim 2008;57:367376.

159 Li SW, Zhang J, Li YM, Ou SH, Huang GY, He ZQ, Ge SX, Xian YL, Pang SQ, Ng MH, Xia NS: A bacterially expressed particulate hepatitis $\mathrm{E}$ vaccine: antigenicity, immunogenicity and protectivity on primates. Vaccine 2005;23:2893-2901.

160 Purcell RH, Nguyen H, Shapiro M, Engle RE, Govindarajan S, Blackwelder WC, Wong DC, Prieels JP, Emerson SU: Preclinical immunogenicity and efficacy trial of a recombinant hepatitis $\mathrm{E}$ vaccine. Vaccine 2003;21:2607-2615.
61 Zhu FC, Zhang J, Zhang XF, Zhou C, Wang ZZ, Huang SJ, Wang H, Yang CL, Jiang HM, Cai JP, Wang YJ, Ai X, Hu YM, Tang Q, Yao X, Yan Q, Xian YL, Wu T, Li YM, Miao J, Ng $\mathrm{MH}$, Shih JW, Xia NS: Efficacy and safety of a recombinant hepatitis $\mathrm{E}$ vaccine in healthy adults: a large-scale, randomised, double-blind placebo-controlled, phase 3 trial. Lancet 2010;376:895-902.

162 Shrestha MP, Scott RM, Joshi DM, Mammen MP Jr, Thapa GB, Thapa N, Myint KS, Fourneau M, Kuschner RA, Shrestha SK, David MP, Seriwatana J, Vaughn DW, Safary A, Endy TP, Innis BL: Safety and efficacy of a recombinant hepatitis $E$ vaccine. N Engl J Med 2007;356:895-903.

163 Proffitt A: First HEV vaccine approved. Nat Biotechnol 2012;30:300.

164 Gerolami R, Borentain P, Raissouni F, Motte A, Solas C, Colson P: Treatment of severe acute hepatitis $\mathrm{E}$ by ribavirin. J Clin Virol 2011;52:60-62.

165 Zhang L, Wilson DP: Trends in notifiable infectious diseases in China: implications for surveillance and population health policy. PLoS One 2012;7:e31076. 